Buletin Ilmiah Math. Stat. dan Terapannya (Bimaster)

Volume 09, No. 1 (2020), hal 65-70.

\title{
ESTIMASI PARAMETER METODE WEIGHTED LEAST SQUARE DALAM MENGATASI MASALAH HETEROSKEDASTISITAS
}

\author{
Hidayatun Nisa, Dadan Kusnandar, Shantika Martha
}

\begin{abstract}
INTISARI
Regresi linear berganda merupakan salah satu metode statistika yang digunakan untuk menganalisis pengaruh antara dua atau lebih variabel independen terhadap variabel dependen. Salah satu asumsi yang harus terpenuhi pada analisis regresi linear berganda adalah tidak terjadinya heteroskedastisitas atau varians error harus tetap (konstan) di dalam model regresi. Metode Weighted Least Square (WLS) merupakan bentuk dari pengembangan penduga least square yang digunakan untuk mengatasi masalah heteroskedastisitas. Tujuan dari penelitian ini adalah menduga parameter metode WLS untuk mengatasi masalah heteroskedastisitas. Data yang digunakan dalam penelitian ini adalah data sosial ekonomi dari 33 provinsi di Indonesia. Data yang dianalisis adalah data tingkat pengangguran terbuka $(Y)$, pertumbuhan ekonomi $\left(X_{1}\right)$, jumlah penduduk $\left(X_{2}\right)$, tingkat partisipasi angkatan kerja $\left(X_{3}\right)$, dan kebutuhan hidup minimum $\left(X_{4}\right)$. Hasil analisis menunjukkan bahwa metode WLS dapat mengatasi masalah heteroskedastisitas. Model regresi yang diperoleh menggunakan metode WLS hanya melibatkan tiga variabel yaitu: $\hat{Y}=30,616+5,640 \times 10^{-5} X_{2}-0,439 X_{3}+2,365 \times 10^{-6} X_{4}$ dengan nilai adjusted $R^{2}$ sebesar 95,49\% yang berarti bahwa besarnya pengaruh variabel jumlah penduduk, tingkat partisipasi angkatan kerja dan kebutuhan hidup minimum terhadap tingkat pengangguran terbuka sebesar 95,49\%.
\end{abstract}

Kata Kunci: regresi linear berganda, transformasi, weighted least square

\section{PENDAHULUAN}

Analisis regresi merupakan suatu metode analisis statistika yang digunakan untuk menganalisis pengaruh antara variabel independen terhadap variabel dependen, dimana variabel independen adalah variabel yang mempengaruhi dan variabel dependen adalah variabel yang dipengaruhi. Analisis regresi menghasilkan suatu model yang menghubungkan variabel dependen dengan variabel independen. Terdapat beberapa metode yang dapat digunakan untuk menduga parameter, salah satunya yaitu metode kuadrat terkecil (ordinary least square). Prinsip metode kuadrat terkecil adalah meminimumkan jumlah kuadrat error. Metode kuadrat terkecil menghendaki beberapa asumsi klasik yang harus terpenuhi yakni error berdistribusi normal, homoskedastisitas, tidak terjadi multikolinearitas dan tidak terjadi autokorelasi [1].

Salah satu metode yang dapat digunakan untuk mengatasi masalah heteroskedastisitas adalah metode Weighted Least Square (WLS). Metode WLS digunakan jika efisiensi estimator dianggap lebih penting daripada sifat unbiased dan konsisten jika dalam kondisi heteroskedastisitas. Metode WLS sama halnya seperti metode OLS yang meminimumkan jumlah kuadrat error, hanya saja pada metode WLS dilakukan pembobotan yang tepat kemudian baru menggunakan metode OLS terhadap data yang telah diboboti.

Data yang digunakan merupakan data sekunder yang diperoleh dari BPS Republik Indonesia tahun 2014 meliputi pertumbuhan ekonomi $\left(X_{1}\right)$, jumlah penduduk $\left(X_{2}\right)$, tingkat partisipasi angkatan kerja $\left(X_{3}\right)$, kebutuhan hidup minimum $\left(X_{4}\right)$ dan variabel dependen adalah tingkat pengangguran terbuka $(Y)$. Setelah data diperoleh tahapan selanjutnya melakukan analisis regresi linear berganda untuk menentukan model regresi dengan menggunakan metode kuadrat terkecil. Selanjutnya melakukan standarisasi data karena variabel-variabel yang diteliti terdapat perbedaan ukuran satuan pada data asli. Kemudian mendeteksi adanya heteroskedastisitas dengan melihat nilai Breusch Pagan (BP). Apabila 
ditemukan adanya heteroskedastisitas pada data, maka selanjutnya menentukan pembobot yang sesuai untuk mengatasi masalah heteroskedastisitas pada data.

Selanjutnya menduga parameter menggunakan metode WLS terhadap data yang telah ditransformasi. Kemudian kembalikan bentuk baku data ke bentuk awal. Kemudian dilanjutkan dengan uji terhadap model secara simultan dengan uji $F$ dan uji individu untuk koefisien regresi dengan uji $t$. Selanjutnya memastikan kembali bahwa sudah tidak terjadi heteroskedastisitas dengan melihat nilai BP. Kemudian langkah terakhir dilanjutkan dengan melihat nilai adjusted $R^{2}$.

\section{ANALISIS REGRESI LINEAR BERGANDA}

Analisis regresi adalah salah satu metode yang biasa digunakan untuk menganalisis hubungan antar dua variabel atau lebih. Hubungan tersebut dapat dituliskan kedalam bentuk persamaan yang menghubungkan variabel dependen $(\mathrm{Y})$ dan variabel independen $(\mathrm{X})$. Model umum dari regresi linier berganda $k$ variabel independen dapat dinyatakan sebagai berikut:

$$
Y_{i}=\beta_{0}+\beta_{1} X_{1 i}+\beta_{2} X_{2 i}+\ldots+\beta_{k} X_{k i}+\varepsilon_{i}
$$

Penduga parameter $\beta_{0}, \beta_{1}, \beta_{2}, \ldots, \beta_{k}$ dapat diperoleh menggunakan metode kuadrat terkecil yang merupakan salah satu penduga parameter dalam model regresi. Tujuan dari metode kuadrat terkecil yaitu meminimumkan jumlah kuadrat (error) pada model yang terbentuk. Penduga parameter metode kuadrat terkecil menggunakan persamaan berikut [2]:

$$
\hat{\beta}=\left(X^{T} X\right)^{-1} X^{T} Y
$$

\section{HETEROSKEDASTISITAS}

Heteroskedastisitas berarti variansi antar error yang satu dengan error yang lain berbeda $\left(\operatorname{var}\left(\varepsilon_{i}\right)=\sigma_{i}^{2}\right)$. Pada kasus heteroskedastisitas, metode kuadrat terkecil akan menjadi tidak efisien dalam menduga koefisien regresi, karena menghasilkan varians yang besar[3]. Jika diasumsikan $E\left(\varepsilon_{i}\right)=0$ dan $E\left(\varepsilon_{i}, \varepsilon_{j}\right)=0$ untuk $i \neq j$, maka bentuk matriks varians kovarians vektor $\varepsilon$ pada kondisi heteroskedastisitas adalah sebagai berikut [4]:

$$
\operatorname{var}(\varepsilon)=\left[\begin{array}{cccc}
\sigma_{1}^{2} & 0 & \cdots & 0 \\
0 & \sigma_{2}^{2} & \cdots & 0 \\
\vdots & \vdots & \ddots & \vdots \\
0 & 0 & \cdots & \sigma_{n}^{2}
\end{array}\right]
$$

\section{WEIGHTED LEAST SQUARE}

Metode Weighted Least Square (WLS) merupakan bentuk pengembangan dari OLS yang digunakan untuk mengatasi masalah heteroskedastisitas. Heteroskedastisitas dalam model regresi terjadi karena ketidaksamaan varians dari vektor error yaitu $\operatorname{var}\left(\varepsilon_{i}\right)$ tidak sama untuk setiap $i$, dinotasikan $\operatorname{var}\left(\varepsilon_{i}\right)=\sigma_{i}^{2}$. WLS merupakan kasus khusus dari Generalized Least Squares. Metode WLS memiliki kemampuan untuk mempertahankan sifat efisiensi estimatornya tanpa harus kehilangan sifat bias dan konsistensinya [5].

Metode WLS diperoleh dengan meminimumkan:

$$
\sum \varepsilon_{i}^{2}=\sum w_{i}\left(Y_{i}-\beta_{0}^{*}-\beta_{1}^{*} X_{1 i}-\beta_{2}^{*} X_{2 i}-\ldots-\beta_{k}^{*} X_{k i}\right)^{2}
$$

dimana $w_{i}$ sebagai pembobot, $\beta_{0}^{*}, \beta_{1}^{*}, \beta_{2}^{*}, \ldots, \beta_{k}^{*}$ adalah penduga kuadrat terkecil tertimbang. 
Metode WLS pada prinsipnya sama dengan metode kuadrat terkecil, bedanya pada metode WLS terdapat penambahan variabel baru yaitu $w$ sebagai pembobot. Penduga parameter $\beta_{0}, \beta_{1}, \beta_{2}, \ldots, \beta_{k}$ untuk regresi linear berganda dengan metode WLS sebagai berikut:

$$
\boldsymbol{\beta}=\left(\boldsymbol{X}^{\prime} \boldsymbol{W} \boldsymbol{X}\right)^{-\mathbf{1}} \boldsymbol{X}^{\prime} \boldsymbol{W} \boldsymbol{Y}
$$

Dalam kenyataannya $\sigma_{i}^{2}$ tidak diketahui sehingga $w$ juga tidak diketahui. Oleh karena itu, untuk menentukan pembobot dapat dilihat dari error terhadap variabel independen, antara lain:

a. Varians error proporsional terhadap $X_{i}^{2}$

$$
E\left(\varepsilon_{i}^{2}\right)=\sigma^{2} X_{i}^{2}
$$

Pendeteksian heteroskedastisitas dapat dilihat menggunakan metode grafik bahwa varians error proporsional terhadap nilai kuadrat dari variabel $X_{i}$ dapat dilihat pada Gambar 1 sebagai berikut:

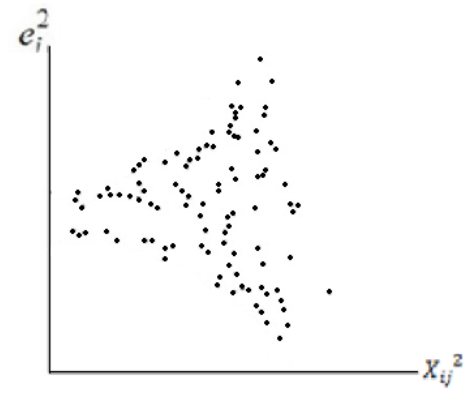

Gambar 1. Varians error proporsional terhadap kuadrat $X_{i}$

Jika pola menunjukkan hubungan kuadrat seperti pada Gambar 1 maka dapat diasumsikan varians dari $\varepsilon_{i}$ proporsional terhadap kuadrat $X_{i}$ sehingga pembobot yang digunakan dalam metode WLS adalah $\frac{1}{X_{i}}$, persamaan regresinya adalah:

$$
\frac{Y_{i}}{X_{i}}=\frac{\left(\beta_{0}+\beta_{1} X_{1 i}+\beta_{2} X_{2 i}+\ldots+\beta_{k} X_{k i}+\varepsilon_{i}\right)}{X_{i}}
$$

b. Varians error proporsional terhadap $X_{i}$

$$
E\left(\varepsilon_{i}^{2}\right)=\sigma^{2} X_{i}
$$

Pendeteksian heteroskedastisitas dapat dilihat menggunakan metode grafik bahwa varians error proporsional terhadap variabel $X_{i}$ itu sendiri dapat dilihat pada Gambar 2 sebagai berikut:

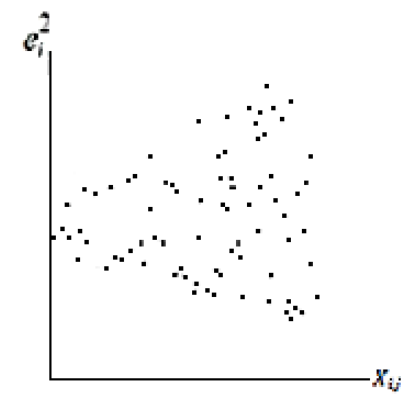

Gambar 2. Varians error proporsional terhadap $X_{i}$

Jika pola menunjukkan hubungan linier seperti pada Gambar 2 maka dapat diasumsikan varians dari $\varepsilon_{i}$ proporsional terhadap $X_{i}$ itu sendiri, sehingga pembobot yang digunakan dalam metode WLS adalah $\frac{1}{\sqrt{X_{i}}}$, persamaan regresinya adalah

$$
\frac{Y_{i}}{\sqrt{X_{i}}}=\frac{\left(\beta_{0}+\beta_{1} X_{1 i}+\beta_{2} X_{2 i}+\ldots+\beta_{k} X_{k i}+\varepsilon_{i}\right)}{\sqrt{X_{i}}}
$$


c. Varians error proporsional terhadap nilai kuadrat rata-rata:

$$
E\left(\varepsilon_{i}^{2}\right)=\sigma^{2}\left[E\left(Y_{i}\right)\right]^{2}
$$

Pendeteksian heteroskedastisitas dapat dilihat menggunakan metode grafik bahwa varians error proporsional terhadap $\left[E\left(Y_{i}\right)\right]^{2}$ dapat dilihat pada Gambar 3 sebagai berikut:

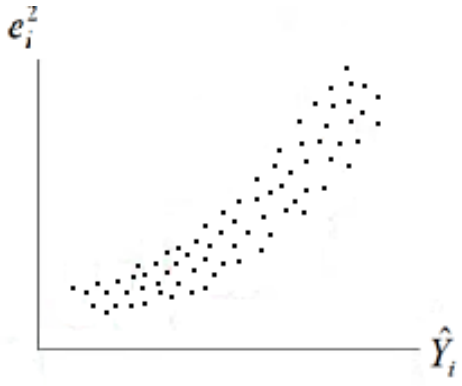

Gambar 3. Varians error proporsional terhadap $\left[E\left(Y_{i}\right)\right]^{2}$

Jika varians error proporsional terhadap $\left[E\left(Y_{i}\right)\right]^{2}$ maka langkah yang akan dilakukan yaitu melakukan regresi metode kuadrat terkecil biasa tanpa memperhatikan heteroskedastisitas untuk mendapatkan $\hat{Y}$, sehingga persamaan regresinya adalah

$$
\frac{Y_{i}}{\hat{Y}_{i}}=\frac{\beta_{0}}{\hat{Y}_{i}}+\beta_{1} \frac{\beta_{1 i}}{\hat{Y}_{i}}+\beta_{2} \frac{\beta_{2 i}}{\hat{Y}_{i}}+\ldots+\beta_{k} \frac{\beta_{k i}}{\hat{Y}_{i}}+\frac{\varepsilon_{i}}{\hat{Y}_{i}}
$$

\section{STUDI KASUS}

Data pada penelitian ini merupakan data sekunder yang diperoleh dari Badan Pusat Statistik (BPS) Republik Indonesia Tahun 2014. Penelitian ini terdiri dari 33 provinsi di Indonesia dengan variabel dependen yaitu tingkat pengangguran terbuka (TPT) dan variabel independen yaitu pertumbuhan ekonomi, jumlah penduduk, tingkat partisipasi angkatan kerja (TPAK), dan kebutuhan hidup minimum (KHM). Data yang diperoleh dilakukan analisis statistik deskriptif setiap variabel seperti yang disajikan pada Tabel 1 sebagai berikut:

Tabel 1 Statistik Deskriptif

\begin{tabular}{ccrrrr}
\hline & N & Minimum & Maximum & \multicolumn{1}{c}{ Mean } & Std. Deviation \\
\hline Pertumbuhan Ekonomi (\%) & 33 & $-0,58$ & 6,79 & 3,73 & 1,69 \\
Jumlah Penduduk (ribu jiwa) & 33 & 849,80 & $46.029,6$ & $7.621,41$ & $10.783,88$ \\
TPAK (\%) & 33 & 59,99 & 78,67 & 66,83 & 3,86 \\
KHM (ribu rupiah) & 33 & 825,00 & $2.399,86$ & $1.579,783$ & 378,42 \\
TPT (\%) & 33 & 1,90 & 10,51 & 5,40 & 2,10 \\
\hline
\end{tabular}

Selanjutnya melakukan standarisasi data karena data yang digunakan pada penelitian ini memiliki ukuran satuan yang berbeda. Kemudian melakukan analisis linear berganda dengan menggunakan metode kuadrat terkecil. Model regresi linear berganda dengan metode kuadrat terkecil persamaan regresinya sebagai berikut:

$$
\hat{Y}=-2,860 \times 10^{-15}-0,236 X_{1}+0,391 X_{2}-0,640 X_{3}+0,306 X_{4}
$$

Tahap berikutnya mendeteksi adanya heteroskedastisitas pada data. Untuk mengetahui apakah terdapat permasalahan heteroskedastisitas pada data tingkat pengangguran terbuka dan faktor-faktor yang mempengaruhinya dilakukan uji heteroskedastisitas dengan menggunakan Uji Breusch Pagan (BP). Kriteria pengambilan keputusan uji signifikansi menyatakan tolak $H_{0}$ apabila nilai BP $<0,05$. Hasil analisis diperoleh nilai BP sebesar 0,0334<0,05 sehingga keputusan yang dapat diambil yaitu tolak $H_{0}$. Dapat disimpulkan bahwa variabel tersebut teridentifikasi masalah heteroskedastisitas. 
Berdasarkan hasil uji BP, diketahui bahwa asumsi homoskedastisitas belum terpenuhi, sehingga selanjutnya melakukan estimasi dengan regresi WLS.

Setelah diketahui data mengandung masalah heteroskedastisitas, selanjutnya menentukan pembobot yang tepat untuk digunakan dalam mengatasi masalah heteroskedastisitas. Pendeteksian untuk pembobot yang tepat dapat dilihat pada Gambar 4 sebagai berikut:

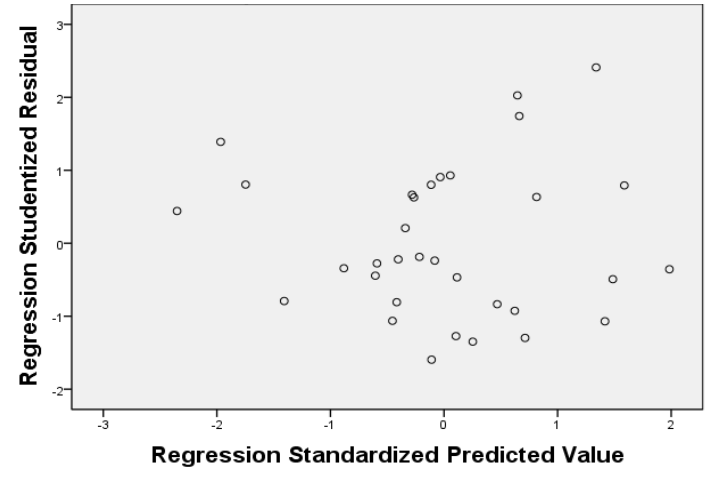

Gambar 4. Diagnostik plot

Pada kasus ini, pembobot yang tepat untuk digunakan dalam mengatasi heteroskedastisitas adalah $\frac{1}{X_{3}}$. Setelah mengestimasi parameter dengan menggunakan metode WLS dengan diberi pembobot yang tepat, langkah selanjutnya menduga model regresi dengan pembobot yang sudah ditentukan dengan metode kuadrat terkecil, sehingga diperoleh hasil sebagai berikut:

Tabel 2 Penduga parameter setelah diberi pembobot

\begin{tabular}{cccl}
\hline Variabel & Estimasi Parameter & Standar error & Sig \\
\hline $\boldsymbol{\beta}_{\mathbf{0}}^{*}$ & $-1,198$ & 0,525 & 0,030 \\
$\boldsymbol{\beta}_{\mathbf{1}}^{*}$ & 0,018 & 0,092 & 0,839 \\
$\boldsymbol{\beta}_{\mathbf{2}}^{*}$ & 0,520 & 0,226 & 0,047 \\
$\boldsymbol{\beta}_{\mathbf{3}}^{*}$ & $-0,822$ & 0,109 & 0,000 \\
$\boldsymbol{\beta}_{\mathbf{4}}^{*}$ & 0,466 & 0,128 & 0,001 \\
\hline
\end{tabular}

Tahap selanjutnya melakukan uji signifikansi regresi pada persamaan yaitu uji signifikansi regresi secara simultan dan secara parsial. Kriteria pengambilan keputusan uji signifikansi menyatakan tolak $H_{0}$ apabila $F_{\text {hitung }}>F_{(\alpha, k-1, n-k)}$. Berdasarkan hasil analisis diperoleh nilai $F_{\text {hitung }}$ sebesar 227,317 dengan taraf signifikansi sebesar 0,05 diperoleh nilai $F_{(0,05 ; 4 ; 28)}$ sebesar 2,71 sehingga keputusan yang dapat diambil yaitu tolak $H_{0}$. Dapat disimpulkan bahwa terdapat hubungan linear antara variabelvariabel independen terhadap variabel dependen.

Kemudian uji signifikansi secara parsial diperoleh bahwa variabel independen yang berpengaruh secara signifikan terhadap tingkat pengangguran terbuka karena nilai $\left|t_{\text {hitung }}\right| \geq t_{(0,025 ; 28)}$ adalah variabel jumlah penduduk, TPAK dan kebutuhan hidup minimum, sedangkan variabel pertumbuhan ekonomi tidak berpengaruh signifikan terhadap variabel tingkat pengangguran terbuka karena nilai $\left|t_{\text {hitung }}\right| \leq t_{(0,025 ; 28)}$.

Setelah diberi pembobot pada data kemudian diuji kembali tanpa memasukkan variabel kebutuhan hidup minimum apakah data tersebut masih terdapat masalah heteroskedastisitas. Kriteria pengambilan keputusan uji signifikansi menyatakan tolak $H_{0}$ apabila nilai $\mathrm{BP}<0,05$. Diperoleh nilai BP sebesar 0,2771 >0,05, sehingga keputusan yang dapat diambil yaitu terima $H_{0}$. Dapat disimpulkan bahwa asumsi homoskedastisitas telah terpenuhi. Berdasarkan hasil tersebut dapat disimpulkan bahwa metode WLS dapat mengatasi masalah heteroskedastisitas dengan faktor-faktor pembobot tertentu.

Selanjutnya dilakukan uji koefisien determinasi untuk mengetahui proporsi pengaruh variabel independen terhadap variabel dependen, diperoleh nilai adjusted $R^{2}$ sebesar 95,49\% yang berarti 
bahwa besarnya pengaruh variabel jumlah penduduk, TPAK dan kebutuhan hidup minimum terhadap tingkat pengangguran terbuka sebesar 95,49\%. Selanjutnya dibentuk model regresi metode WLS tanpa menyertakan pertumbuhan ekonomi dikarenakan pada uji $t$ dinyatakan bahwa pertumbuhan ekonomi tidak berpengaruh signifikan terhadap tingkat pengangguran terbuka. Koefisien penduga yang diperoleh pada WLS masih dalam bentuk baku, maka dikembalikan ke dalam bentuk awal sebagai berikut:

$$
\begin{array}{ll}
\beta_{2}=\left(\frac{S_{Y}}{S_{x_{2}}}\right) \beta_{2}^{*}=5,640 \times 10^{-5} & \beta_{3}=\left(\frac{S_{Y}}{S_{x_{3}}}\right) \beta_{3}^{*}=-0,439 \\
\beta_{4}=\left(\frac{S_{Y}}{S_{x_{4}}}\right) \beta_{4}^{*}=2,365 \times 10^{-6} & \beta_{0}=\bar{Y}-\sum_{j=1}^{p} \beta_{j} \bar{X}_{j}=30,616
\end{array}
$$

\section{KESIMPULAN}

Hasil analisis faktor-faktor yang mempengaruhi tingkat pengangguran terbuka di Indonesia terdapat perbedaan yang signifikan pada variabel pertumbuhan ekonomi $\left(X_{1}\right)$, jumlah penduduk $\left(X_{2}\right)$, tingkat partisipasi angkatan kerja $\left(X_{3}\right)$, kebutuhan hidup minimum $\left(X_{4}\right)$. Berdasarkan dari ke empat variabel hanya tiga variabel yang berpengaruh signifikan, diperoleh persamaan regresi sebagai berikut:

$$
\hat{Y}=30,616+5,640 \times 10^{-5} X_{2}-0,439 X_{3}+2,365 \times 10^{-6} X_{4}
$$

Model yang diperoleh menunjukkan variabel jumlah penduduk $\left(X_{2}\right)$, tingkat partisipasi angkatan kerja $\left(X_{3}\right)$ dan kebutuhan hidup minimum $\left(X_{4}\right)$ berpengaruh secara signifikan terhadap tingkat pengangguran terbuka dengan nilai adjusted $R^{2}$ sebesar 95,49\% yang berarti bahwa besarnya pengaruh variabel jumlah penduduk, TPAK dan kebutuhan hidup minimum terhadap tingkat pengangguran terbuka sebesar $95,49 \%$.

\section{DAFTAR PUSTAKA}

[1]. Maziyya, P.A., Sukarsa, I.K.G., Asih, N.M. Mengatasi Heteroskedastisitas pada Regresi dengan Menggunakan Weighted Least Square (WLS). E-Jurnal Matematika. Vol. 4. No. 1: 20-25; 2015.

[2]. Widyaningsih, A., Susilawati, M., dan Sumajaya, I.W. Estimasi Model Seemingly Unrelated Regression (SUR) dengan Metode Generalized Least Square (GLS). E-Jurnal Matematika, Vol. 4 No. 2: 102-110; 2014.

[3]. Sugiarti,H. dan Megawarni, A., Tingkat Efisiensi Metode Regresi Robust dalam Menaksir Koefisien Garis Regresi Jika Ragam Galat Tidak Homogen, J. Matematika, Sains, dan Teknologi., Vol. 6:17-24; 2005.

[4]. Rencher, A.C. Linear Models in Statistics, John Wiley \& Sons, Hoboken, New Jersey; 2008.

[5]. Gujarati, D.N. Dasar-Dasar Ekonometrika Buku 1, Ed ke-5, Salemba Empat, Jakarta; 2010.

\section{HIDAYATUN NISA}

DADAN KUSNANDAR

SHANTIKA MARTHA
: Jurusan Matematika FMIPA UNTAN, Pontianak hidayatunisa06@gmail.com

: Jurusan Matematika FMIPA UNTAN, Pontianak dkusnand@untan.ac.id

: Jurusan Matematika FMIPA UNTAN, Pontianak shantika.martha@math.untan.ac.id 